\title{
Spatial-Based Information System for Early Precaution of Dengue Hemorrhagic Fever
}

\section{Yulianti, N. ${ }^{1}$; Mursid Raharjo ${ }^{2}$; Eko Sediyono ${ }^{3}$}

\author{
${ }^{1}$ Public Health Office, Tegal Regency, Indonesia \\ Email: yulianti.buroyo@gmail.com \\ ${ }^{2}$ Faculty of Public Health,University of Diponegoro, Indonesia \\ Email: mursidraharjo@gmail.com \\ ${ }^{3}$ Faculty of Informatics, University of Kristen Saty a Wacana, Indonesia \\ Email: ekosed1@yahoo.com
}

\begin{abstract}
Dengue hemorrhagic fever (DHF) case in Tegal is quite high. In recent years (2016-2018), there has been an outbreak of dengue hemorrhagic fever which resulted in 24 deaths. In this regard, a fast and accurate control system is needed. One of them is spatial-based interactive information system for DHF. This study aimed to develop a spatial-based DHF information system that produced complete, accurate, easily accessible, and punctual information. DHF information system developed was website-based. This research was a research survey with qualitative approach. Qualitative data were collected by observation and interview methods. Sampling based on purposive sampling method. System development using the FAST method. Pre and Post data collection time approaches by assessing respondents' perceptions of the quality of information produced by the system before and after the development of the information system. The result of this study was a spatial-based interactive DHF information system with output map of the location of DHF cases according to the patient's address and DHF risk factors in the form of ABJ and altitude. Testing the quality of information before and after the development of the DHF information system, showed a weighted average increase in five aspects of information quality.
\end{abstract}

Keywords—Information system; Dengue hemorrhagic fever; Spatial; FAST.

\section{INTRODUCTION}

Dengue Hemorrhagic Fever (DHF) is a disease caused by Aides Aegepty mosquito bites.(Republik Indonesia, 2013, 2017)The total case of DHF in Indonesia in 2018 was 65,602 cases with an Incidence rate (IR) of 24.73 and Case Fertility Rate (CFR) of 0, 70\%.(Ministry of Health Indonesia, 2019; Republik Indonesia, 2019)Compared to cases in 2017, there was a decrease in the number of IRs and CFRs (IR = 26.10 and CFR = 0.72).(Kementerian Kesehatan, 2018)

Tegal regency, which mostly consists of coastal and lowland areas, is a DHF endemic area. In 2015, the DHF incidence rate (IR) reached 30 per 100,000 populations, and then increased to 43 in 2016. In 2016,Tegal regency got the highest number of DHF cases Central Java with 610 cases $(\mathrm{IR}=43)$ and 18 deaths $(\mathrm{CFR}=2.95 \%)$. (Dinas Kesehatan Kabupaten Tegal, 2018)DHF cases decreased in $2017(\mathrm{IR}=18, \mathrm{CFR}=1.1 \%)$ and $2018(\mathrm{IR}=4.6, \mathrm{CFR}=$ $1.5 \%$ ) with peak of DHF cases occurred in January.(Jateng, 2018)

Based on these conditions, Tegal regency government prioritizes prevention and control programs to prevent the increase in DHF cases.(Dinas Kesehatan Kabupaten Tegal,
2019) Prevention and control of DHF has been done by conducting epidemiological surveillance activities. Epidemiological surveillance is a systematic and continuous monitoring of data and information about pathological events or health problems and conditions which affect the occurrence of a disease or health problem.(Kesehatan, 2014) DHF epidemiological surveillance is carried out actively and passivelyby tracking cases and compiling DHF case reports from the health service facility. Case tracking has been carried out with epidemiological investigations in 20 houses around the houses of DHF patients who were treated in hospitals and public health centers (Puskesmas).(Suroso, 2010) The implementation of DHF surveillance in Public Health Office Tegal regency had a problem in data management. It was less informative and incomplete (recording, reporting, and presenting surveillance data). The database management system for DHF had not been implemented, resulting in difficulties and more time in searching, storing and accessing data.(Yulianti, 2019)It caused the difficulty of detecting areas in the context of early precaution.(Republik Indonesia, 2017) 
The development of spatial-based DHF information systems was an action to solve existing problems. Information systems can input, store and analyze DHF data while presenting reports in the form of tables, graphs and maps.(Prahasta, 2001) Spatial-based information systems display DHF case data together with DHF determinants (risk factors), so they can provide more complete, fastand informative information for early precaution.(Budiyanto, 2002)

The purpose of this study was to produce spatial-based DHF information system by website in Tegal regency.

\section{RESEARCH METHOD}

This research was an action research with a qualitative approach. The method used was in-depth interview observation and distribution of questionnaires. Observations were made to see the flow and performance of the existing system. In-depth interviews were conducted to explore the problems and needs of users. Whereas, the questionnaire was used to assess the quality of the information system before and after the development of the system (pre and posttests).

Sampling was based on purposive sampling method, which is sampling with a specific purpose. In this case the sample was the official or officer who handled the prevention and control of DHF.(Sugiyono, 2015)

The subjects of the study were the head of department, section head, DHF programmers, DHF surveillance officers at the public health service, and DHF data officers at the hospital. The study was conducted in March-June 2019 in Tegal regency.

System development was carried out using FAST (Framework for the Application of System Techniques) method. It is chosen since it can adapt to the current technology changes and development, so it will be more flexible if the developed information system will be renew in the future. FAST method has seven stages: a preliminary study, problem analysis, needs analysis, decision analysis, design, construction, and implementation.(Arif M, 2017; Jeffrey \& Kevin, 2004)

\section{RESULT AND DISCUSSION}

DHF case report at the Tegal regency Public Health Office have been carried out through WhatsApp groups and recorded by using Microsoft Excel program. Case reporting was started from Public Health Center and hospitals which treated DHF patients to the Public Health Office. Then, it was followed up with an order to the Public Health Center staff to carry out epidemiological investigations (PE) around the patient's residence. The results of epidemiological investigations were recorded in the PE form and reported back to the office (hardcopy). The results of $\mathrm{PE}$ included larvae free rate (ABJ), additional DHF patients, case location, and altitude.

\subsection{Informative Spatial-Based DHF Information System}

The first stage is preliminary study. It employed properness study, an assessment of whether or not a DBD information system is appropriate to develop. Researchers implemented the assessment of technical, economical, operational, and scheduled properness. In the preliminary study, it was concluded that DHF information system was feasible to be developed.(Indrajid, 2000; Jogiyanto, 2005)

On the second stage, the researchers conducted the investigation on the problems and weakness of the recent system.(Masrochah, 2016)The problem found during the interview and observations was the difficulty of the officers to entry, save, edit and print the data of DHF report. DHF data and information were incomplete, especially PE data where the paper base had not been inputted into the system. Often, there was a double entry of patient data in which the data that has been reported by the Public Health Center was reported back by the hospital. In addition, data and information could not be accessed at all because they needed to open the officer's laptop to obtain it. Finally, the problem was punctuality, where the reports were often late so decision making for the prevention and control of DHF was not done in time.

The third stage is need analysis. The problem found from the user was that the current system could not accommodate the needs of the user. Users needed a system that was easy to operate, complete, appropriate, accurate and punctual.

On the fourth stage. The decision analysis, it was decided to make a DHF web-based information system design with multiuser. It is recently needed because it is online. The systemcan be accessed anytime and anywhere. The system developed has three users, Public Health Office, Public Health Center, and hospitals.

The next stage was to design the information system based on user needs. Data sources in the DHF information system were case reports from hospitals, inpatient Public Health Center (KDRS forms) and reports of the results of epidemiological investigations (PE forms). The following is the context diagram of DHF information system: 


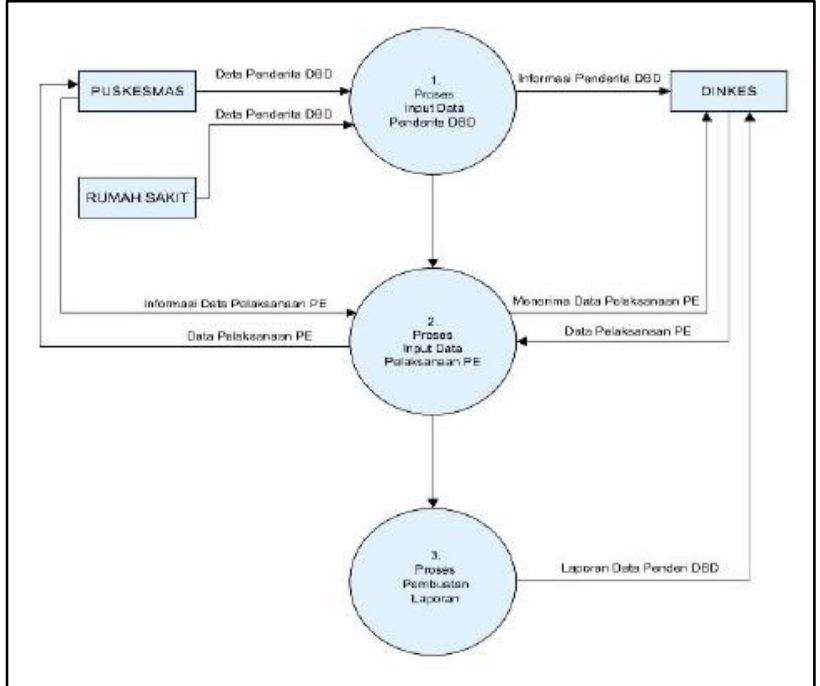

Fig.1: The context diagram of DHF information system

Fig. 1 explained about the input, process, and output of spatial-based interactive DHF information system. The users of this system were Public Health Centers, hospitals and Public Health Office. Public Health Center and hospitals had the duty to input data into the system. Public Health Center input the data of DHF patients treated (specifically for inpatient Public Health Center) and PE results (inpatient and outpatient). In contrast, hospitals only entered the data of patients with DHF who were treated in hospitals. The Public Health Office was in charge of receiving DHF patient's data reports from Public Health Center and hospitals, ordering Public Health Center to carry out PE, and receiving reports from the system.

There were three processes in the spatial-based DHF information system, the patients data input, the input process for implementing $\mathrm{PE}$, and the process of making reports.

The sixth stage, system construction had four menus namely the menu of DHF patients' data, reports, user management, and changing passwords. Patient data menu included patient data according to the KDRS form and data from the implementation of PE (ABJ, patient location, and altitude). The report menu contained DHF case reports based on age, gender, occupation, healthcare location, and a map of case locations. Next, there was the user management menu which functioned to add, change, and deactivate user accounts. The last was the menu to change the password to maintain account security. Passwords which were often changed would make it difficult for others to break into the systems.

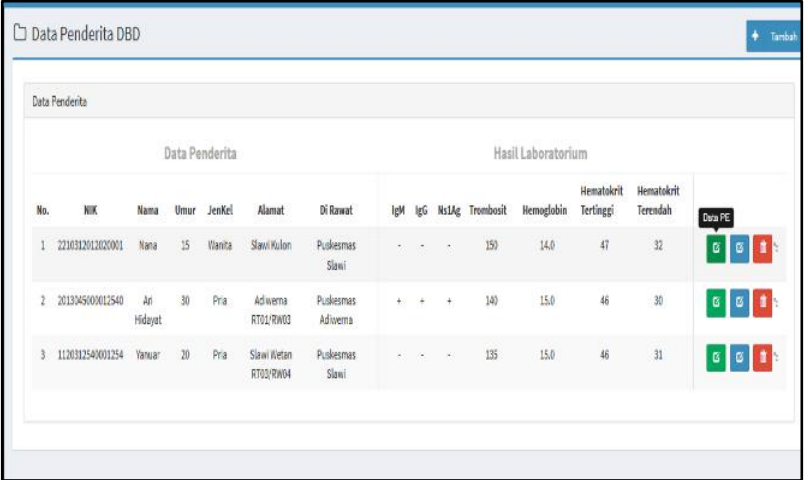

Fig.2: Menu of Patient's Data

Fig. 2 showed the menu of patient's data which consisted of identity, result of laboratory, and PE data. Entry data of the patients and PE data resulted in case reports. The case reports could be downloaded in the form of table, graphic, and map.

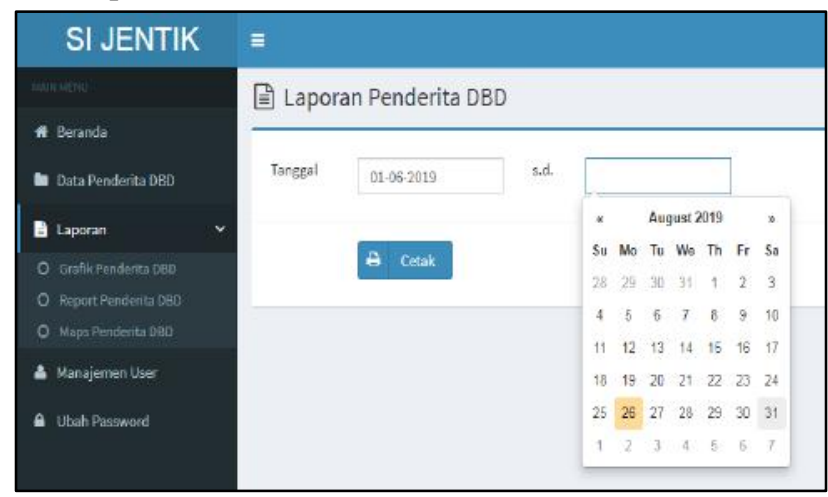

Fig.3: Menu of DHF Patient Report

Fig.3 showed the menu of DHF patient report which could be downloaded based on the time needed, which were weekly, monthly, quarterly or semester in pdf form.

One of the outputs in DHF system information was the location map of the case which included ABJ, altitude, residence, and $\mathrm{PE}$ follow-up. The map shows exactly the case point, so it can be used for the early vigilance of DHF Special Occurrence. The location map is shown in the following figure:

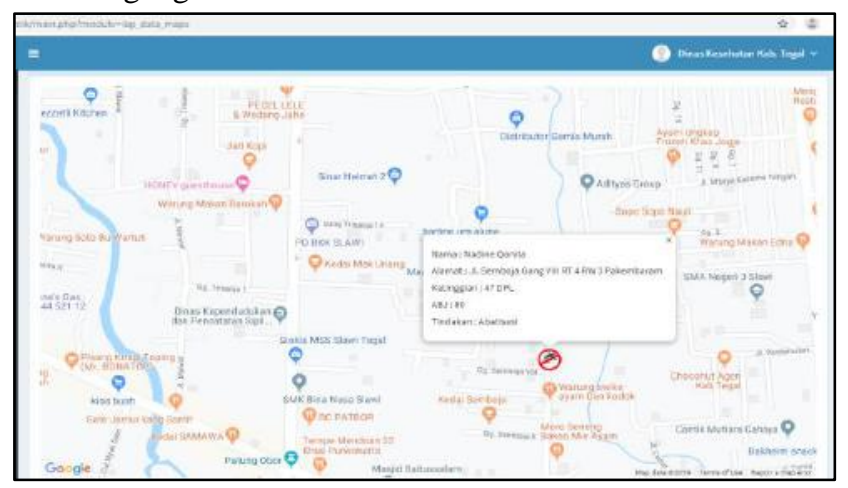

Fig.4: Location Map of DHF Case 
The seventh stage in developing the system according to the FAST method is implementation. The system made was implemented at the Public Health Office, two Public Health Centers and two hospitals. Users were first introduced and trained on spatial-based DHF information system. Then the user was given a username and password to be able to login and use the system access rights.

\subsection{Information Quality Test}

Information quality test was carried out twice, which were done before the system was developed and after the system was finished. After the systemcould be operated according to its function, a test was done to the system. The test was carried out for one month which included socialization, training and application of the system to the Public Health Office, Public Health Center, and sample hospital. Users filled out a questionnaire about aspects of convenience, completeness, availability, accuracy, and punctuality.

The average score of the five aspects before the development of the system was 1.41. The results of the assessment after using the system were 4.49. Difference in average value before and after using the system was 3.08. There was an increase in the quality of information compared to the system that had been used. Problems faced by users could be overcome by implementing spatial-based interactive DHF information system.

\section{CONCLUSION}

Based on the research, it can be concluded that:

1. The problem of the DHF information system in the Tegal Regency Public Health Office consisted of completeness, availability, convenience, accuracy, and punctuality of data and information.

2. Development of aspatial-based interactive DHF information system with a web base at the Tegal Regency Public Health Office was in accordance with the FAST stages.

3. Spatial-based interactive DHF information system created a map of environmental risk factors for DHF according to patient's location.

4. The quality of information on spatial-based interactive DHF information system had average value of 3.08 , where the system was considered better and able to solve data and information problems.

\section{ACKNOWLEDGEMENT}

Our gratitude is delivered to the Head of the Regional Development Planning and Research Center (Bappeda \& Litbang) of the Tegal Regency government for providing the opportunity to carry out this research.

\section{REFERENCES}

[1] Arif M. (2017). Pemodelan Sistem (1st ed.). Yogy akarta: Deepublish.

[2] Budiyanto, E. (2002). Sistem informasi geografis menggunakan arc view GIS. Andi offset.

[3] Dinas Kesehatan Kabupaten Tegal. (2018). Profil Kesehatan Kabupaten Tegal 2017.

[4] Dinas Kesehatan Kabupaten Tegal. (2019). Profil Kesehatan Kabupaten Tegal 2018. Slawi: Dinas Kesehatan Kab. Tegal.

[5] Indrajid, R. (2000). Manajemen Sistem Informasi dan Tekhnologi Informasi. Jakarta: PT Elex Medi Komputindo.

[6] Jateng, D. P. (2018). Pertemuan Koordinasi Program DBD Kabupaten Tegal.

[7] Jeffrey, L., \& Kevin, C. D. (2004). System Analysis ang Design Methods. indianapolis: The McGraw-Hill Companies Inc.

[8] Jogiyanto, H. (2005). Analisis dan Desain Sistem Informasi: Pendekatan Terstruktur Teori dan Aplikasi Bisnis III. Yogy akarta: Andi offset.

[9] Kementerian Kesehatan. (2018). Data dan Informasi Profil Kesehatan Indonesia 2017. (D. drg. Rudy Kurniawan, M.Kes, Ed.). Jakarta: Kementerian Kesehatan RI.

[10] Kesehatan, P. S. Permenkes Nomor 45 Tahun 2014, Pub. L. No. No. 45 Tahun 2014, 1 (2014). Indonesia.

[11] Masrochah, S. (2016). Sistem Informasi Pemantauan Kejadian Luar Biasa (KLB) Demam Berdarah Berbasis Geographic Information System (GIS) di Kota Semarang. Jurnal Riset Kesehatan, 5(2), 53-59.

[12] Ministry of Health Indonesia. (2019). Profil Kesehatan Indonesia 2018 [Indonesia Health Profile 2018]. ( dkk drg. Rudy Kurniawan, M.Kes, Ed.). Jakarta: Kementerian Kesehatan RI. Retrieved from http://www.depkes.go.id/resources/download/pusdatin/prof il-kesehatan-indonesia/Data-dan-Informasi_ProfilKesehatan-Indonesia-2018.pdf

[13] Prahasta, E. (2001). Konsep-konsep dasar sistem informasi geospasial. Bandung: Penerbit Informatika.

[14] Republik Indonesia, kementerian kesehatan. (2013). Buku saku. Jakarta: Kementerian Kesehatan RI.

[15] Republik Indonesia, kementerian kesehatan. (2017). Pedoman Pencegahan dan Pengendalian Demam Berdarah Dengue di Indonesia. Jakarta.

[16] Republik Indonesia, kementerian kesehatan. (2019). Data dan Informasi Profil Kesehatan Indonesia 2018. ( dkk drg. Rudy Kurniawan, M. Kes, Ed.). Jakarta: Kementerian Kesehatan RI.

[17] Sugiyono, P. D. (2015). Metode Penelitian Kuantitatif, Kualitatif, dan $R \& D$ (22nd ed.). Bandung: CV. Alfabeta.

[18] Suroso, T. (2010). Pencegahan dan Penanggulangan Penyakit Demam Dengue dan Demam Berdarah Dengue. Jakarta: Kementerian Kesehatan RI.

[19] Yulianti, N. (2019). Rekayasa Sistem Informasi DBD Interaktif Berbasis Spasial di Kabupaten Tegal. Universitas Diponegoro. 